\title{
Effect of Phytogenic Mixture Supplementation on Carcass Characteristics and Cost of Production in Broiler Chickens during Winter Season
}

\author{
Vishal Sharma ${ }^{1 *}$, Devender Singh Bidhan ${ }^{1}$, Sanjay Yadav ${ }^{2}$, Yogesh C. Bangar ${ }^{3}$ and Dipin Chander Yadav ${ }^{1}$ \\ ${ }^{1}$ Department of Livestock Production Management, College of Veterinary Sciences, Lala Lajpat Rai University of Veterinary and \\ Animal Sciences, Hisar, Haryana, INDIA \\ ${ }^{2}$ Department of Livestock Products Technology, LUVAS, Hisar, INDIA \\ ${ }^{3}$ Department of Animal Genetics and Breeding, LUVAS, Hisar, INDIA \\ *Corresponding author: V Sharma; E-mail: drvishalsharma2112@gmail.com
}

Received: 29 Nov., 2019

Revised: 13 Dec., 2019

Accepted: 12 Jan., 2020

\begin{abstract}
In present experiment 288 day-old commercial broiler chicks were subjected to eight dietary treatments consisting of three replicates of twelve chicks in each replicate were reared for a period of 6 weeks in winter season. The dietary treatments includes: $\mathrm{T}_{0}$ - Negative control, $\mathrm{T}_{1}$-control, $\mathrm{T}_{2}-0.5 \%$ Amla $+0.5 \%$ Ashwagandha $+0.25 \%$ Turmeric powder, $\mathrm{T}_{3}-0.25 \%$ Amla + $0.5 \%$ Ashwagandha $+0.25 \%$ Turmeric powder, $\mathrm{T}_{4}-0.125 \%$ Amla $+0.5 \%$ Ashwagandha $+0.25 \%$ Turmeric powder, $\mathrm{T}_{5}-0.5 \%$ Amla $+0.25 \%$ Ashwagandha $+0.25 \%$ Turmeric powder, $\mathrm{T}_{6}-0.5 \%$ Amla $+0.125 \%$ Ashwagandha $+0.25 \%$ Turmeric powder and $\mathrm{T}_{7}-0.5 \%$ Amla $+0.5 \%$ Ashwagandha $+0.125 \%$ Turmeric powder. Standard managemental practices were followed during the experimental period. Supplementation of phytogenic mixture consisting of $0.5 \%$ amla and $0.5 \%$ Ashwagandha with $0.25 \%$ or $0.125 \%$ turmeric powder $\left(\mathrm{T}_{2}\right.$ and $\left.\mathrm{T}_{7}\right)$ gave best results and improved the giblet percentage, eviscerated weight percentage and drawn percentage in winter season. The cost of production of drawn weight $(₹ / \mathrm{kg})$ of broilers at six weeks of age was reduced as much as ₹ $10.23\left(\mathrm{~T}_{2}\right)$ and ₹ $9.48\left(\mathrm{~T}_{7}\right)$ in winter season. The study concluded that addition of $0.5 \%$ amla and $0.5 \%$ Ashwagandha with $0.25 \%$ or $0.125 \%$ turmeric powder can be effectively supplemented as an alternative to antibiotics growth promoter in poultry ration in winter for improving the carcass characteristics and such ration was found more economical in comparison to that having antibiotic growth promoter.
\end{abstract}

Keywords: Broilers, phytogenic mixture, amla, Ashwagandha, turmeric, season

Poultry is one of the fastest growing segments of livestock in India. Poultry today not only act as an income stabilizer but also provides regular and timely income as compared to livestock and crop farming. The main objective of modern broiler farming is faster growth, high feed conversion efficiency livability and production of quality meat. The economics of production is very important criteria for broiler production where feed is the major important factor affecting the productive performance and economics of broiler production, next to genetic potential. In the past, the major growth promoters were antibiotics which have been found helpful in improvement of growth performance and feed conversion ratio in poultry (Miles et al., 2006 and Dibner and Buttin, 2002). However the use of antibiotics is being placed under more and more pressure as consumers increasingly fear that their use in the rations of poultry leads to the formation of resistance against bacteria which are pathogenic to humans (Langhout, 2000). Therefore, due to negative effects on health, use of antibiotics in poultry is banned in many countries (Owens et al., 2008; Alcicek et al., 2004; Botsoglou and Fletouris, 2001; Hertrampf, 2001). Herbs, spices and various plant extracts have received attention as possible replacement to antibiotic growth promoters. These are generally recognized as safe both for animals as well as humans; environmentally

How to cite this article: Sharma, V., Bidhan, D.S. ., Yadav, S., Bangar, Y.C and Yadav, D.C. (2020). Effect of phytogenic mixture supplementation on carcass characteristics and cost of production in broiler chickens during winter season. J. Anim. Res., 10(1): 85-89. 
friendly; can be applicable in the diets of poultry and thus, address organic livestock production (Cabuk et al., 2006). Amla (Emblica officinalis), Ashwagandha (Withania somnifera) and Turmeric (Curcuma longa) are known medicinal plant of therapeutic importance. They possess antistress, adaptogenic, immunogenic and other properties resulting in better performance of broilers. Keeping in view the facts stated above, the present study was planned to observe the effects of supplementation of phytogenic mixture on the carcass characteristics and economics of cost of production.

\section{MATERIALS AND METHODS}

\section{Location of study}

The present investigation was conducted at the Poultry Farm of the Department of Livestock Production Management, College of Veterinary Sciences, LalaLajpatRai University of Veterinary and Animal Sciences (LUVAS), Hisar. The experiment was approved by the Institutional Animal Ethics Committee.

\section{Experimental design}

288 one-day-old broiler chicks of Ven-Cobb strain-400 were purchased from a reputed local hatchery. The chicks were randomly distributed into eight treatment groups each having 36 chicks namely; $\mathrm{T}_{0}$ - Negative control, $\mathrm{T}_{1}$-control, $\mathrm{T}_{2}-0.5 \%$ Amla $+0.5 \%$ Ashwagandha $+0.25 \%$ Turmeric powder, $\mathrm{T}_{3}-0.25 \%$ Amla $+0.5 \%$ Ashwagandha $+0.25 \%$ Turmeric powder, $\mathrm{T}_{4}-0.125 \%$ Amla $+0.5 \%$ Ashwagandha $+0.25 \%$ Turmeric powder, $\mathrm{T}_{5}-0.5 \%$ Amla $+0.25 \%$ Ashwagandha $+0.25 \%$ Turmeric powder, $\mathrm{T}_{6}-0.5 \%$ Amla $+0.125 \%$ Ashwagandha $+0.25 \%$ Turmeric powder and $\mathrm{T}_{7}-0.5 \%$ Amla $+0.5 \%$ Ashwagandha $+0.125 \%$ Turmeric powder. Further each group was further divided into three replicates of 12 chicks each.

\section{Experimental procedure}

The chicks were reared under strict hygienic conditions. Chicks were vaccinated against new castle disease (F1 strain) on $5^{\text {th }}$ day and Infectious bursal disease (IBD) on $14^{\text {th }}$ day of experiment through intra-ocular route. Standard managemental practices including brooding, proper lighting, raking of litter, cleaning of feeders, waterers, etc. were followed. Before formulation of broiler rations, the feed ingredients were analyzed (AOAC, 2005) for proximate composition. Based upon the proximate composition of feed ingredients, the broiler pre-starter, starter and finisher rations were formulated according to BIS (2007) specifications (Table 1).

Table 1: Quantity of ingredients and chemical Composition (\% DM basis) of experimental diet ( $\mathrm{kg} / 100 \mathrm{~kg}$ feed)

\begin{tabular}{|c|c|c|c|}
\hline \multirow[b]{2}{*}{ Name of Ingredients } & \multicolumn{3}{|l|}{ Quantity } \\
\hline & $\begin{array}{l}\text { Pre-starter } \\
\text { (0-1 week) }\end{array}$ & $\begin{array}{l}\text { Starter (2-3 } \\
\text { weeks) }\end{array}$ & $\begin{array}{l}\text { Finisher } \\
\text { (4-6 weeks) }\end{array}$ \\
\hline Maize & 55 & 55.5 & 60 \\
\hline Soyabean meal & 20 & 17 & 15 \\
\hline Ground nut cake & 12.5 & 13.5 & 10 \\
\hline Fish meal & 8 & 8 & 8 \\
\hline Mineral mixture & 2 & 2 & 2 \\
\hline Vegetable oil & 2.5 & 4 & 5 \\
\hline $\begin{array}{l}\text { Feed additives }(\mathrm{g} / 100 \mathrm{~kg} \\
\text { of ration) }\end{array}$ & 0-1 week & 2-3 weeks & 4-6 weeks \\
\hline Intermix (g) & 10 & 10 & 10 \\
\hline Intermix BE (DS) (g) & 20 & 20 & 20 \\
\hline Coccicheck (g) & 50 & 50 & 50 \\
\hline Choline chloride (g) & 50 & 50 & 50 \\
\hline Lysine (g) & 50 & 50 & 50 \\
\hline DL - methionine $(\mathrm{g})$ & 80 & 80 & 80 \\
\hline Chemical composition & Pre-starter & Starter & Finisher \\
\hline Moisture \% & 10.54 & 10.83 & 10.87 \\
\hline Crude protein \% & 23.05 & 22.05 & 20.09 \\
\hline Crude fibre \% & 3.63 & 3.60 & 3.31 \\
\hline Ether extract \% & 6.96 & 8.38 & 8.99 \\
\hline Total ash \% & 6.32 & 6.18 & 5.87 \\
\hline Nitrogen free extract $\%$ & 49.50 & 48.96 & 50.87 \\
\hline $\begin{array}{l}\text { Metabolizable energy } \\
(\mathrm{Kcal} / \mathrm{Kg})\end{array}$ & 2950 & 3055 & 3160 \\
\hline
\end{tabular}

*Mineral mixture (salt free): Ca (32\%), P (6\%), Mn (0.27\%), Zn $(0.26 \%)$, Iodine $(0.01 \%), \mathrm{Fe}(1000 \mathrm{ppm}), \mathrm{Cu}(100 \mathrm{ppm})$, and $\mathrm{Co}$ $(50 \mathrm{ppm}) ; \uparrow$ Intermix regular: Each gm contained Vitamin A-82,500 IU, Vit. $B_{2}-50 \mathrm{mg}$, Vit. $\mathrm{D}_{3}-16,500 \mathrm{IU}$, and Vit. K-10mg.; $\$$ Intermix BE (DS) Powder: Each gm contained Vit. $B_{1}-8 \mathrm{mg}$, Vit. $\mathrm{B}_{6}-16 \mathrm{mg}$, Vit. $B_{12}-80 \mathrm{mg}$, Niacin- $120 \mathrm{mg}$, $\S$ Vit. E- $80 \mathrm{mg}$, folic acid-6 mg and Calcium pentothenate $-80 \mathrm{mg}$.; || Coxicheck: Amprolium-200 mg, vitamin $\mathrm{K}_{3}-10 \mathrm{mg}$.; $\mid$ Lysine: Contained 98 per cent lysine; ** DLmethionine: Contained 98 per cent methionine; $\dagger \dagger$ Choline chloride: Contain 60 percent choline. 


\section{Observations recorded}

\section{Carcass characteristics}

At the end of the experiment 9 birds per treatment (three from each replicate) were randomly selected. The birds were kept off feed for 12 hours prior to their sacrifice, but water was given ad libitum. Weight of the birds, before and after fasting, was recorded. Immediately after recording their live weights, the birds were slaughtered by severing the jugular vein at the atlanto-occipital joint and allowed to bleed completely. Simultaneously blood sample for estimation of haemato-biochemical parameters of each bird was collected from jugular vein. Later their heads were separated at atlanto-occipital joint and shanks were cut out at hock joints. After removal of skin along with feathers, the carcass weight was recorded. It is called dressed yield and expressed as per cent of pre-slaughter weight. Dressed birds were then eviscerated by removing the crop, trachea and viscera as a whole. A horizontal cut was given rear to the keel bone; thereby the breast was a little upturned and pushed forward, exposing the viscera along with the visceral organs, which were then removed completely by pulling. The lungs were scrapped off.

Heart, liver and gizzard constituting giblets, were removed carefully from the viscera. The gall bladder was removed with care from liver to avoid its rupture. The gizzard was opened and its contents were washed out and inner epithelial lining was discarded. The heart was made free from blood and adhering vessels. The eviscerated and drawn weights were recorded and their percentages were calculated. Similarly weight of giblets (heart, liver and gizzard) was recorded after washing and bloating, and giblet yield (percentage of live weight) was also calculated.

\section{Cost of production}

Relative cost of production was calculated at the end of sixth week. The cost of production included the cost of chick survived and the cost of feed consumed among the treatments to know which dietary supplementation was more profitable.

\section{Statistical analysis}

Data obtained were subjected to statistical analysis as per Snedecor and Cochran (1994) using Completely Randomized Design (CRD). The mean differences among different treatments were separated by Duncan's multiple range tests. Consequently, a level of $(\mathrm{P}<0.05)$ was used as the criterion for statistical significance (Duncan, 1955).

\section{RESULTS AND DISCUSSION}

\section{Carcass characteristics}

The carcass characteristics of broilers reared under different treatments, recorded at 42 days of age, is presented in Table 2. There was significant difference among treatments regarding different carcass characteristics such as drawn percentage, eviscerated percentage and giblet percentage. However, dressing percentage was statistically non-significant $(\mathrm{P}<0.05)$. The mean values of dressing percentage, drawn percentage, eviscerated percentage and giblets percentage ranged from $74.33\left(\mathrm{~T}_{0}\right)$ to $75.89\left(\mathrm{~T}_{7}\right)$, $65.85\left(\mathrm{~T}_{0}\right)$ to $69.19\left(\mathrm{~T}_{7}\right), 60.43\left(\mathrm{~T}_{0}\right)$ to $62.90\left(\mathrm{~T}_{7}\right)$ and 5.42 $\left(\mathrm{T}_{0}\right)$ to $6.32\left(\mathrm{~T}_{2}\right)$, respectively. The mean values of drawn percentage, eviscerated percentage and giblet percentage of birds in $\mathrm{T}_{2}, \mathrm{~T}_{3}, \mathrm{~T}_{4}, \mathrm{~T}_{5}, \mathrm{~T}_{6}$ and $\mathrm{T}_{7}$ were significantly better than $\mathrm{T}_{1}$.

Table 2: Effect of phytogenic mixture on mean carcass characteristics of broiler meat in winter season

\begin{tabular}{|c|c|c|c|c|c|c|c|c|}
\hline \multirow{2}{*}{ Parameter } & \multicolumn{8}{|c|}{ Treatments } \\
\hline & $\bar{T}$ & $\mathbf{T}$ & $\mathbf{T}$ & $\mathbf{T}$ & $\mathbf{T}$ & $\mathbf{T}$ & $\mathbf{T}$ & $\mathbf{T}$ \\
\hline Dressing percentage & $\begin{array}{l}74.33 \pm \\
1.83\end{array}$ & $\begin{array}{l}75.37 \pm \\
1.63\end{array}$ & $\begin{array}{l}75^{2} .87 \pm \\
1.57\end{array}$ & $\begin{array}{l}75.53 \pm \\
1.61\end{array}$ & $\begin{array}{l}75.35 \pm \\
1.64\end{array}$ & $\begin{array}{l}75.56 \pm \\
1.56\end{array}$ & $\begin{array}{l}75.24 \pm \\
1.54\end{array}$ & $\begin{array}{l}75.89 \pm \\
1.58\end{array}$ \\
\hline Drawn percentage & $\begin{array}{l}65.85^{\mathrm{a}} \pm \\
0.17\end{array}$ & $\begin{array}{l}66.44^{\mathrm{a}} \pm \\
0.17\end{array}$ & $\begin{array}{l}68.62^{\mathrm{d}} \pm \\
0.13\end{array}$ & $\begin{array}{l}67.37^{\mathrm{b}} \pm \\
0.14\end{array}$ & $\begin{array}{l}67.68^{\mathrm{bc}} \pm \\
0.15\end{array}$ & $67.71^{b c} \pm 0.14$ & $\begin{array}{l}67.74^{\mathrm{c}} \pm \\
0.11\end{array}$ & $\begin{array}{l}69.19^{\mathrm{e}} \pm \\
0.16\end{array}$ \\
\hline Eviscerated percentage & $\begin{array}{l}60.43^{\mathrm{a}} \pm \\
0.13\end{array}$ & $\begin{array}{l}60.66^{\mathrm{a}} \pm \\
0.14\end{array}$ & $\begin{array}{l}62.30^{\mathrm{d}} \pm \\
0.13\end{array}$ & $\begin{array}{l}61.24^{\mathrm{b}} \pm \\
0.12\end{array}$ & $\begin{array}{l}61.45^{\mathrm{bc}} \pm \\
0.13\end{array}$ & $\begin{array}{l}61.54^{\mathrm{bc}} \pm \\
0.11\end{array}$ & $\begin{array}{l}61.67^{\mathrm{c}} \pm \\
0.13\end{array}$ & $\begin{array}{l}62.90^{\mathrm{e}} \pm \\
0.14\end{array}$ \\
\hline Giblets percentage & $\begin{array}{l}5.42^{\mathrm{a}} \pm \\
0.03\end{array}$ & $\begin{array}{l}5.78^{\mathrm{b}} \pm \\
0.07\end{array}$ & $\begin{array}{l}6.32^{\mathrm{g}} \pm \\
0.05\end{array}$ & $\begin{array}{l}6.13^{\mathrm{cd}} \pm \\
0.06\end{array}$ & $\begin{array}{l}6.23^{\mathrm{ef}} \pm \\
0.04\end{array}$ & $\begin{array}{l}6.17^{\text {de }} \pm \\
0.03\end{array}$ & $\begin{array}{l}6.07^{\mathrm{c}} \pm \\
0.09\end{array}$ & $\begin{array}{l}6.29^{\text {fg }} \pm \\
0.05\end{array}$ \\
\hline
\end{tabular}

Values are means \pm standard errors; Means bearing different superscripts, differ significantly $(\mathrm{P}<0.05)$ row wise. 
The results of present study are comparable to that of Singh et al. (2007) reported improved giblet weights in broilers fed diets with amla, turmeric powder and their combination. Al-Kassie et al. (2011) observed no significant difference between treatments and control group in dressing percentage when fed mixture cumin and turmeric at the rate of $0.00,0.25,0.50,0.75$ and $1 \%$ in broiler diet.

In contrast, Findings of Singh et al. (2007) reported improved dressing percentage in broilers fed diets with amla, turmeric powder and their combination. Kurkure et al. (2002) stated that dressing per cent and liver per cent on live weight were better in herbal premix fed group having amla as an integral part. Godara (2012) reported that supplementation of Ashwagandha (1\%) and Probiotic $(0.05 \%)$ during hot weather resulted in no significant difference between the treatments regarding carcass characteristics.

\section{Cost of production}

The cost of production of broilers, considering the cost of chicks and feed consumed up to six weeks of age, reared under different treatments is presented in Table 3. At the start of experiment there were thirty-six birds in each treatment group. The cost of chicks was calculated on the basis of birds survived at the end of experiment under each treatment. The initial cost of one-day-old broiler chicks was ₹ 40.00 per chick and ₹ 50 per chick during winter and summer season respectively. This cost raised to the tune of $43.64\left(\mathrm{~T}_{0}\right), 42.35\left(\mathrm{~T}_{1}\right)$, and $41.14\left(\mathrm{~T}_{3}\right)$ in winter season and $54.54\left(\mathrm{~T}_{0} \& \mathrm{~T}_{1}\right)$ and $51.43\left(\mathrm{~T}_{4}\right)$ in summer season respectively. Feed cost was calculated to be $₹ 30.19$ per $\mathrm{kg}$ of feed during winter and summer season. Phytogenic mixture comprising of Amla, Ashwagandha and Turmeric were purchased @ of ₹ 200/Kg, ₹ 500/Kg and ₹ 120/Kg respectively. The total cost of production of birds up to six weeks of age, based upon the cost of chicks, cost of feed consumption as well as cost of phytogenic mixture consumed up to this age, ranged from $₹ 133.38\left(\mathrm{~T}_{5}\right)$ to $148.95\left(\mathrm{~T}_{4}\right)$ and $150.51\left(\mathrm{~T}_{5}\right)$ to $165.27\left(\mathrm{~T}_{4}\right)$ in winter and summer season respectively. The cost per kilogram of live weight in winter and summer season and ranged from ₹ $77.63\left(\mathrm{~T}_{5}\right)$ to $90.38\left(\mathrm{~T}_{0}\right)$ and $₹ 92.53\left(\mathrm{~T}_{2}\right)$ to $113.24\left(\mathrm{~T}_{0}\right)$, respectively. The cost per kilogram of drawn weight in winter and summer season and ranged from ₹ $114.65\left(\mathrm{~T}_{5}\right)$ to $137.25\left(\mathrm{~T}_{0}\right)$ and $₹ 133.8\left(\mathrm{~T}_{2}\right)$ to $171.78\left(\mathrm{~T}_{0}\right)$, respectively.

Table 3: Cost of production of broilers under different treatments at the end of experiment during winter season

\begin{tabular}{|c|c|c|c|c|c|c|c|c|c|}
\hline \multirow{2}{*}{$\begin{array}{l}\text { Sl. } \\
\text { No }\end{array}$} & \multirow{2}{*}{ Particulars } & \multicolumn{8}{|c|}{ Treatments } \\
\hline & & $T_{0}$ & $T_{1}$ & $\mathbf{T}_{2}$ & $\mathbf{T}_{3}$ & $\mathbf{T}_{4}$ & $T_{5}$ & $T_{6}$ & $\mathbf{T}_{7}$ \\
\hline 1 & $\begin{array}{l}\text { Live body weight at } 6^{\text {th }} \text { week of } \\
\text { age }(g)\end{array}$ & 1525.88 & 1682.41 & 1839.92 & 1695.83 & 1711.86 & 1718.19 & 1727.69 & 1795.17 \\
\hline 2 & Drawn percentage & 65.85 & 66.44 & 68.62 & 67.37 & 67.68 & 67.71 & 67.74 & 69.19 \\
\hline 3 & $\begin{array}{l}\text { Total feed consumption up to } 6^{\text {th }} \\
\text { week of age }(\mathrm{g})\end{array}$ & 3122.44 & 3242.08 & 3107.66 & 3189.52 & 3277.93 & 2852.71 & 3211.74 & 3082.97 \\
\hline 4 & Feed cost (₹) per kilogram feed & 30.19 & 30.19 & 30.19 & 30.19 & 30.19 & 30.19 & 30.19 & 30.19 \\
\hline 5 & Total feed cost (₹) & 94.27 & 97.88 & 93.82 & 96.29 & 98.96 & 86.12 & 96.96 & 93.07 \\
\hline 6 & Chick cost (₹) & 43.64 & 42.35 & 40.0 & 41.14 & 40.0 & 40.0 & 40.0 & 40.0 \\
\hline 7 & Cost of Antibiotics (₹) & 0 & 0.5 & 0 & 0 & 0 & 0 & 0 & 0 \\
\hline 8 & Cost of phytogenics (₹) & 0 & 0 & 11.84 & 10.52 & 9.99 & 7.26 & 10.09 & 11.24 \\
\hline 9 & $\begin{array}{l}\text { Total cost of production up to six } \\
\text { week (₹) }\end{array}$ & 137.91 & 140.43 & 145.66 & 147.95 & 148.95 & 133.38 & 147.05 & 144.31 \\
\hline 10 & $\begin{array}{l}\text { Cost of Production/Kg of live } \\
\text { body weight (₹) }\end{array}$ & 90.38 & 83.47 & 79.17 & 87.24 & 87.01 & 77.63 & 85.11 & 80.39 \\
\hline 11 & $\begin{array}{l}\text { Cost of Production/Kg of drawn } \\
\text { weight (₹) }\end{array}$ & 137.25 & 125.66 & 115.43 & 129.5 & 128.56 & 114.65 & 125.65 & 116.18 \\
\hline 12 & $\begin{array}{l}\text { Net Savings/Kg of Drawn weight } \\
\text { (₹) }\end{array}$ & -11.59 & 0 & 10.23 & -3.94 & -2.9 & 11.01 & 0.01 & 9.48 \\
\hline
\end{tabular}


The effect of supplementation of phytogenic mixture depicted that the cost of production of drawn weight (₹/ $\mathrm{kg})$ at six weeks of age was reduced as much as $₹ 11.01$ $\left(\mathrm{T}_{5}\right)$, ₹ $10.23\left(\mathrm{~T}_{2}\right)$, ₹ $9.48\left(\mathrm{~T}_{7}\right)$ and ₹ $0.01\left(\mathrm{~T}_{6}\right)$ as compared to $\mathrm{T}_{1}$ (control) in winter season. The corresponding values for cost of production of drawn weight $(₹ / \mathrm{kg})$ in summer season were reduced as much as $₹ 22.25\left(\mathrm{~T}_{2}\right)$, ₹ $17.26\left(\mathrm{~T}_{7}\right)$, ₹ $16.39\left(\mathrm{~T}_{5}\right)$, ₹ $13.79\left(\mathrm{~T}_{6}\right)$, ₹ $10.89\left(\mathrm{~T}_{3}\right)$, and ₹ $3.41\left(\mathrm{~T}_{4}\right)$.

The results of present study are comparable to that of Jadhav et al. (2008) who concluded that dietary supplementation of Ashwagandha root powder and ascorbic acid was economical as the net profit per bird was higher with supplementation. Chaudhary et al. (2015) concluded that the supplementation of herbal mixture (Curcuma longa, Emblica officinalis and Nigella sativa) at $1 \%$ level in broiler diet resulted in better economic return and this mixture could be used as a phytobiotic in place of antibiotic feed additives in broiler.

\section{Acknowledgements}

The authors are thankful to Lala Lajpat Rai University of Veterinary and Animal Sciences, Hisar, Haryana for providing necessary funds and facilities for smooth conduct of this research.

\section{CONCLUSION}

From the results of present investigation it can be concluded that addition of $0.5 \%$ amla and $0.5 \%$ Ashwagandha with $0.25 \%$ or $0.125 \%$ turmeric powder can be a promising alternative to antibiotics growth promoter in poultry ration for improving the carcass characteristics of broilers. Besides this, such ration was found more economical in comparison to that having antibiotic growth promoters.

\section{REFERENCES}

Alcicek, A., Bozkurt, M. and Cabuk, M. 2004. The effect of a mixture of herbal essential oils, an organic acid or a probiotic on broiler performance. S. Afr. J. Anim. Sci., 34: 217-222.

Al-Kassie, G., Mohseen, A.M. and Abd-Al-Jaleel, R.A. 2011. Modification of productive performance and physiological aspects of broilers on the addition of a mixture of cumin and turmeric to the diet. Res. Opin. Anim. Vet. Sci., 1: 31-34.

A.O.A.C. 1995. Official method of analysis. $16^{\text {th }}$ Edn. Association of Official Analytical Chemist, Arlington.Virginia.
BIS. 2007. Requirement for chicken feeds. IS: 1374-2007, Manak Bhavan, 9 Bahadurshah Zafar Marg, New Delhi-110001.

Botsoglou and Fletouris. 2001. Drug residues in foods: Pharma, food safety and analysis. $1^{\text {st }}$ Edn., Marcel Dekker, New York.

Cabuk, M., Bozkurt, M., Alcicek, A., Akbas, Y. and Kucukyilmaz, K. 2006. Effect of a herbal essential oil mixture on growth and internal organ weight of broilers from young and old breeder flocks. South African J. Anim. Sci., 36: 135-141.

Chaudhary, R.K., Singh, V.K., Singh, S.P., Gautam, S. and Tewari, D. 2015. Effect of herbal supplements of Curcuma longa, Emblica officinalis and Nigella sativa on performance of broilers. Indian J. Anim. Nutr., 32(1): 90-95.

Dibner, J.J. and Buttin, P. 2002. Use of organic acid as a model to study the impact of gut microflora on nutrition and metabolism. J. Appl. Poult. Res., 11: 453-463.

Duncan, D.B. 1955 Multiple range and multiple $F$ tests. Biometrics, 11: 1-42.

Godara, M. 2012. Effect of Ashwagandha (Withania somnifera) and probiotic on the performance of broilers during hot weather. M.V.Sc. Thesis, LUVAS, Hisar.

Hertrampf, J.W. 2001. Alternative antibacterial performance promoters. Poult. Int., 40: 50-55.

Jadhav, S.S., Mandlekar, S.M., Choudhari, A.J., Shinde, S.V. and Kharkar, K.P. 2008. Effect of supplementation of ashwagandha and ascorbic acid as antistress agents on growth performance and immune status of broilers during hot weather. Royal Vet. J. India, 4: 60-63.

Kurkure, N.V., Kalorey, D.R. and Ali, M.H. 2002. Herbal nutraceuticals: An alternative to antibiotic growth promoters. Poult. Fortune, 31-32.

Langhout, D.J., Schutte, J.B., De Jong, J., Sloetjes, H., Verstegen, W.A. and Tamminga, S. 2000. Effect of viscosity on digestion of nutrients in conventional and germ-free chicks. British $J$. Nutr., 83(5): 533-540.

Miles, R.D., Butcher, G.D., Henry, P.R. and Littell, R.C. 2006. Effect of antibiotic growth promoters on broiler performance, intestinal growth parameters and quantitative morphology. Poult. Sci., 85: 476-485.

Owens, B., Tucker, L., Collins, M.A. and McCracken, K.J. 2008. Effects of different feed additives alone or in combination on broiler performance, gut microflora and ileal histology. Brit. Poult. Sci., 49: 202-212.

Singh, G., Maurya, S. and Catalan, C.A. 2007. A comparison of chemical, antioxidant and antimicrobial studies of cinnamon leaf and bark volatile oils, oleoresins and their constituents. Food Chem. Toxicol., 45(9): 1650-1661.

Snedecor, G.W. and Cochran, W.G. 1994. Statistical method. $8^{\text {th }}$ edition. Oxford and IBG publication Co., New Delhi, India. 
